\title{
EXPLORING HOW SMARTPHONES SUPPORTS STUDENTS' LIVES
}

\author{
Kamal K. Hingorani, Alabama State University, khingorani@alasu.edu \\ Donald Woodard, Alabama State University, dwoodard@alasu.edu \\ Nasrin Askari-Danesh, Alabama State University,ndanesh@alasu.edu
}

\begin{abstract}
Smartphone usage in the US has exploded, jumping from just $18 \%$ in the third quarter of 2009 to $44 \%$ during the third quarter of 2011. Smartphones today have features that are comparable to an average computer, and this handheld mobile device can engage students in far more dynamic ways than a laptop or tablet computer. This study explores the penetration of smartphones among college students and how smartphones are being used by them.
\end{abstract}

Keywords: Information Technology (IT), Smartphones, Cell Phones Usage and Civility, Mobile Devices, Classroom.

\section{INTRODUCTION}

Smartphones have become extremely popular and constitute an ever-increasing share of computing platforms. For example, in the fourth quarter of 2011, as per estimates provided by Gartner, 92.2 million PCs were sold worldwide. In that same quarter, 149 million smartphones were sold [7, 8]. The sale of PCs declined by $1.4 \%$ in the fourth quarter, whereas the sale of smart phones increased by a staggering $58 \%$ during the same period.

Smartphone usage in the US has also exploded, jumping from just $18 \%$ in the third quarter of 2009 to $44 \%$ during the third quarter ending in October 2011 according to the Nielsen Mobile Media Report [12]. Usage is across all age ranges, and young adults remain the most likely to own a smartphone: 53\% of U.S. cell phone users are aged 18 to 24, and 64\% of smartphone users are aged 25 to 34. A February 2012 survey of students at Ball State University in Indiana noted this growth, with smartphone ownership on their campus more than doubling in three years-from $27 \%$ in 2009 to $69 \%$ in 2012 [1].

The cellphone is a ubiquitous device among university students and has had a profound impact on their lives [2, 6 , $10,15,16]$. Access to social media sites, such as Facebook and Twitter, and features such as texting have captured the attention of our students, and many students spend a considerable amount of time utilizing these features. In a recent survey, college students said their professors would be "shocked" to know just how often they send text messages during lectures [4].

Use of cell phones by students in the classroom is a major challenge to most professors. Today, many syllabi contain statements banning the use of cell phones in the classroom, and many universities have also issued written policies to this effect. Universities, on the other hand, also encourage use of cellphones to stay connected for a safer campus, to advertise events and happenings on the campus, and to promote the university brand among their students.

This study explores the penetration of smartphones among college students at a southeast US university and how these smartphones are being used by the students.

\section{LITERATURE REVIEW}

In order to shape their curricula to meet the demands of increasingly connected students, universities and educators are turning their focus on how students use technology. Currently, smartphones are far more powerful tools than an average computer. According to University of Michigan's electrical engineering and computer science professor Elliot Soloway, "in a student's capable hands, especially with numerous features like a camera, a GPS, and an accelerometer, a smartphone might as well be a rocket ship" [14]. 


\section{Issues in Information Systems}

Volume 13, Issue 2, pp. 33-40, 2012

\section{SOCIAL MEDIA AND SMARTPHONES}

Facebook and Twitter have continued to gain popularity on college campuses. It would be difficult to walk around a college campus without seeing several students using these social media sites. The average time spent accessing Facebook via smartphone in the United States was 441 minutes in March 2012 compared with 391 minutes via computer. This underscores the increasingly high-profile role of smartphones in social networking. Other popular services for smartphones include: check-in services Foursquare, with 146 minutes; microblogging service Twitter, with 114 minutes; and blogging-service Tumblr, with 68 minutes [3].

According to Alexa, the Internet site which provides traffic data and global rankings, Facebook ranked $2^{\text {nd }}$ in traffic among all websites while Twitter was ranked $8^{\text {th }}$. The other important statistics of these two sites are shown in Table-1.

Table-1: Statistics Summary (source: http://www.alexa.com)

Data for April 25, 2012

\begin{tabular}{|c|c|c|c|c|c|}
\hline & Traffic rank & Reach $^{\top}$ & Page Views ${ }^{2}$ & $\begin{array}{l}\text { Page } \\
\text { Views/User }\end{array}$ & $\begin{array}{l}\text { Time on Site } \\
\text { (Minutes: Seconds) }\end{array}$ \\
\hline Facebook & 2 & $44.58 \%$ & $5.144 \%$ & 12.65 & 23.20 \\
\hline Twitter & 8 & $9.81 \%$ & $0.4413 \%$ & 4.93 & 6.59 \\
\hline
\end{tabular}

${ }^{1}$ Estimated percentage of global internet users who visit the site

${ }^{2}$ Estimated percentage of global page views at the site

${ }^{3}$ Estimated daily unique page views per user for the site.

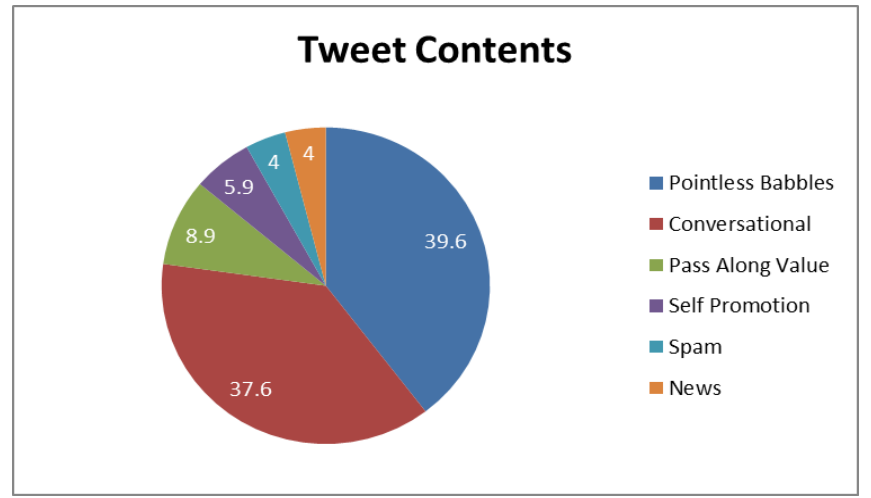

Figure-1: Tweet Contents

Twitter is popular for the immediacy it provides. We have seen an increased use of Twitter among our students and wanted to gain more insight on the popularity of Twitter. We were also interested in finding out the content of the students' tweets. Our pilot revealed that such information cannot be accurately gathered through a questionnaire survey. We plan to explore the possibility of doing a content analysis. There are issues of privacy, but we plan to run this as a project asking students to do this analysis as a group. The tweet contents are shown in Figure-1 [3].

\section{THE CONSTRUCT OF NOMOPHOBIA}

Nomophobia is the fear of being without a mobile phone. The term is an abbreviation for "no-mobile-phone phobia". Although this word was coined in 2008, there have been no studies to develop a construct to measure it. Since there is a growing dependence on cellphones/smartphones among college students, this exploratory study tried to develop a construct by using seven items on the survey:

1. I like to use my smartphone to keep in touch no matter where I am.

2. I feel safer because I can always use my smartphone to get help. 


\section{Issues in Information Systems}

Volume 13, Issue 2, pp. 33-40, 2012

3. It is a lot of trouble to keep my smartphone with me all the time.

4. When I am bored, I use my smartphone to entertain myself.

5. I like that my smartphone makes it easy to change plans quickly.

6. I get irritated when a call or text on my smartphone interrupts me.

7. My smartphone gives me more freedom because I can stay in touch.

These items were measured on a five-point Likert scale (1-Strongly Agree..... 5-Strongly Agree). We wanted to develop a construct with adequate reliability as measured by Cronbach's alpha.

Our research was conducted to survey students enrolled in the introductory CIS class on their use of mobile devices and the internet. Special emphasis was laid on cell-phones so that the data could be compared to a nation-wide study conducted on the use of cell-phones by teenagers.

\section{RESEARCH METHODOLOGY}

The survey was designed in-house using ASP.Net and was administered on the Internet. A total of 134 students from MIS classes participated in the survey. The demographics of the survey respondents are shown in Table- 2 .

Table-2: Demographics of Survey Respondents

\begin{tabular}{|l|l|l|}
\hline Demographic Category & Frequency & Percentage - \% \\
\hline & & \\
\hline Classification & & \\
\hline Freshmen & 21 & 15.7 \\
\hline Sophomore & 56 & 41.8 \\
\hline Junior & 38 & 28.4 \\
\hline Senior & 19 & 14.2 \\
\hline & & \\
\hline Gender & & \\
\hline Male & 71 & 53 \\
\hline Female & 63 & 47 \\
\hline & & \\
\hline Major & & \\
\hline Accounting & 17 & 12.7 \\
\hline Computer Information Systems & 51 & 38.1 \\
\hline Finance & 4 & 3.0 \\
\hline Management & 20 & 14.9 \\
\hline Marketing & 8 & 6.0 \\
\hline Others & 34 & 25.3 \\
\hline
\end{tabular}

The survey had a total of 24 questions. The questions included items on use of smartphones and social media in addition to the construct for nomophobia. The analysis included frequencies, descriptive statistics, exploratory factor analysis, and Anova using SPSS.

\section{RESULTS}

Personal ownership of mobile devices is shown in Table-3. All the 134 students (100\%) surveyed owned a cellphone. $79 \%$ of them owned a smartphone, $85 \%$ of them owned a laptop, and only $20 \%$ of them owned an iPad. 


\section{Issues in Information Systems}

Volume 13, Issue 2, pp. 33-40, 2012

\begin{tabular}{|l|l|r|l|l|}
\hline \multicolumn{5}{|c|}{ Table-3: Ownership of Mobile Devices } \\
\hline Cell phone & Smart & Voice + Text & Laptop & iPad \\
\hline $134(100 \%)$ & $107(79.9 \%)$ & $27(20.1 \%)$ & $116(85 \%)$ & $27(20 \%)$ \\
\hline
\end{tabular}

$57 \%$ of the students owned a Samsung, Droid, or HTC cellphone, which are powered by Android. The iPhone was owned by $36 \%$ of the students surveyed. The details are shown in Table- 4 .

\begin{tabular}{|l|r|r|r|r|r|}
\hline \multicolumn{7}{|c|}{ Table-4: Make of Cell Phones } \\
\hline & iPhone & Samsung & Droid & HTC & Other \\
\hline Count & 36 & 28 & 28 & 20 & 22 \\
\hline$\%$ & $27 \%$ & $21 \%$ & $21 \%$ & $15 \%$ & $16 \%$ \\
\hline
\end{tabular}

Students spent a considerable amount of money for their cell phone services as shown in Table-5. Over 50\% of the students had monthly expenditures in excess of $\$ 75$ for their cellphone services. The details are shown in Table-5.

\begin{tabular}{|l|r|r|r|r|}
\hline \multicolumn{5}{|c|}{ Table-5: Cost of Cell Phone Services } \\
\hline & $<\$ 50$ & $\$ 50-\$ 75$ & $\$ 75-\$ 100$ & $>\$ 100$ \\
\hline Count & 35 & 32 & 36 & 31 \\
\hline$\%$ & $26 \%$ & $24 \%$ & $27 \%$ & $23 \%$ \\
\hline
\end{tabular}

Cell phones are not just about calling or texting - with expanding functionality, phones have become multimedia recording devices and pocket-sized internet connected computers. The ubiquitous cellphone served as the primary camera for $79 \%$ of the respondents; the primary music player for $62 \%$ of the students; the primary video recorder for $72 \%$ of the students; and the primary digital gaming device for $49 \%$ of the students. The details are shown in Table6.

\begin{tabular}{|l|r|r|r|r|}
\hline \multicolumn{7}{|c|}{ Table-6: Cell Phone the Primary } \\
\hline & Camera & Music Player & Video Recorder & Gaming \\
\hline Count & $\mathbf{1 0 6}$ & $\mathbf{8 3}$ & $\mathbf{9 7}$ & $\mathbf{6 6}$ \\
\hline$\%$ & $79 \%$ & $62 \%$ & $72 \%$ & $49 \%$ \\
\hline
\end{tabular}

The data revealed the importance of Facebook to the student community with over $92 \%$ of the students having an active account on this social-media site. $81 \%$ of the students had an active account on Twitter. Google+ and YouTube were also popular. Only 14\% of the students had an active LinkedIn account. None of the freshmen and sophomores had an account with LinkedIn. The details are shown in Table-7.

\begin{tabular}{|c|c|c|c|c|c|}
\hline \multicolumn{7}{|c|}{ Table-7: Active Accounts on } \\
\hline & Facebook & Twitter & LinkedIn & Google+ & YouTube \\
\hline & $124(92 \%)$ & $109(81 \%)$ & $19(14 \%)$ & $87(65 \%)$ & $87(65 \%)$ \\
\hline
\end{tabular}

Twitter was ranked as the most popular social media site by $44 \%$ of the students. Facebook was the favorite site for $43 \%$ of the students. YouTube was ranked the most popular by $9 \%$ of the students. The details are shown in Table- 8 .

\begin{tabular}{|l|l|l|l|l|}
\hline \multicolumn{5}{|c|}{ Table-8: Most Popular Social Networking Site } \\
\hline Facebook & Twitter & LinkedIn & Google+ & YouTube \\
\hline $58(43 \%)$ & $59(44 \%)$ & $0(0 \%)$ & $4(3 \%)$ & $13(9 \%)$ \\
\hline
\end{tabular}




\section{Issues in Information Systems}

Volume 13, Issue 2, pp. 33-40, 2012

All the students surveyed used text messaging on their cell phones with over $38 \%$ sending over 50 messages a day. $82 \%$ of the students tweeted daily with over $21 \%$ tweeting more 20 times of day. The details are shown in Table-9.

\begin{tabular}{|c|l|r|r|r|r|r|r|r|}
\hline \multicolumn{8}{|c|}{ Table-9: Number of Tweets and Text Messages per day } \\
\hline & & None & $1-10$ & $11-20$ & $21-50$ & $51-100$ & $101-200$ & $>200$ \\
\hline \multirow{2}{*}{ Text } & Count & 0 & 13 & 15 & 25 & 29 & 25 & 27 \\
\cline { 2 - 9 } & $\%$ & $0.0 \%$ & $9.7 \%$ & $11.2 \%$ & $18.7 \%$ & $21.6 \%$ & $18.7 \%$ & $20.1 \%$ \\
\hline \multirow{2}{*}{ Tweets } & Count & 24 & 57 & 28 & 14 & 15 & 0 & 0 \\
\cline { 2 - 9 } & $\%$ & $17.9 \%$ & $42.5 \%$ & $20.9 \%$ & $10.4 \%$ & $11.2 \%$ & $0.0 \%$ & $0.0 \%$ \\
\hline
\end{tabular}

The tweeter profile of the students is shown in Table-10. The survey was not designed to capture the TFF Ratio (Twitter Follower-Friend Ratio) - the ratio of followers to friends (or people who you follow). The higher the ratio, the more "Twitter heat" you pack according to the twitter dictionary.

\begin{tabular}{|l|r|r|r|r|r|}
\hline \multicolumn{5}{|c|}{ Table-10: Number of Followers/Following on Twitter } \\
\hline & \multicolumn{1}{|c|}{ None } & \multicolumn{1}{c|}{50} & \multicolumn{1}{c|}{$50-100$} & $100-200$ & \multicolumn{1}{l|}{200} \\
\hline Following & 25 & 16 & 12 & 24 & 57 \\
\hline Follower & 25 & 18 & 13 & 60 & 18 \\
\hline
\end{tabular}

The average Twitter user has 27 followers; Lady Gaga, the top twitterholic, has 23,887,513 followers.

Although the College of Business has a policy banning the use of cellphones in the classroom, students continue to use cellphones in the classrooms. The use of cell phones in the classroom is shown in Table-11. The responses for these items were measured on a 5-point Likert-like scale (Several times a Day, At least once a Day, A few times a week, Less often, Never).

\begin{tabular}{|l|l|l|r|l|r|r|}
\hline \multicolumn{2}{|c|}{ Table-11: Cell Phone in the Classroom } \\
\hline & & $\begin{array}{l}\text { Several times a } \\
\text { Day }\end{array}$ & $\begin{array}{l}\text { At least once } \\
\text { a Day }\end{array}$ & $\begin{array}{l}\text { A few times a } \\
\text { week }\end{array}$ & $\begin{array}{l}\text { Less } \\
\text { often }\end{array}$ & Never \\
\hline \multirow{3}{*}{ Cell Phone on in class } & $\%$ & 113 & 9 & 6 & 4 & 2 \\
\hline \multirow{3}{*}{ Receive call in class } & Count & $84.3 \%$ & $6.7 \%$ & $4.5 \%$ & $3.0 \%$ & $1.5 \%$ \\
\cline { 2 - 8 } & $\%$ & 28 & 19 & 11 & 40 & 36 \\
\hline \multirow{3}{*}{ Receive text in class } & Count & $20.9 \%$ & $14.2 \%$ & $8.2 \%$ & $29.9 \%$ & $26.9 \%$ \\
\cline { 2 - 8 } & $\%$ & $77.5 \%$ & $12.7 \%$ & $11.9 \%$ & $14.9 \%$ & $3.0 \%$ \\
\hline
\end{tabular}

Only $6 \%$ of the students had never sent or received text messages in the classroom. Over $63 \%$ of the students had made or received calls in the classroom while over $96 \%$ of the students had received a text in the class. The students were not supportive of university policy, as evidence by the response to the question "The College's no cell phone in the class room is fair" (Mean=2.87, $\mathrm{SD}=1.49$ ). This data also reveals the extent of the problem facing instructors as we try to get their students' undivided attention.

An Exploratory Factor Analysis with a Varimax (orthogonal) rotation of the seven Likert scale questions from the survey was conducted. The mean and standard deviation of these items are shown in Table-12. The results of the factor analysis are shown in Table-13. An examination of the Kaiser-Meyer Olkin measure of sampling adequacy suggested that the sample was factorable $(\mathrm{KMO}=.668)$. 


\section{Issues in Information Systems}

Volume 13, Issue 2, pp. 33-40, 2012

Table-12 Descriptive Statistics

\begin{tabular}{|c|c|c|c|c|c|}
\hline Survey Question & $\mathrm{N}$ & Min. & Max. & Mean & SD \\
\hline My cell phone gives me more freedom because I can stay in touch. & 134 & 2 & 5 & 4.64 & 0.67 \\
\hline I like that my cell phone makes it easy to change plans quickly. & 134 & 1 & 5 & 4.22 & 0.97 \\
\hline I feel safer because I can always use my cell phone to get help. & 134 & 2 & 5 & 4.63 & 0.68 \\
\hline I like to use my cell phone to keep in touch no matter where I am. & 134 & 1 & 5 & 4.74 & 0.61 \\
\hline When I am bored, I use my cell phone to entertain myself. & 134 & 1 & 5 & 4.43 & 0.86 \\
\hline It is a lot of trouble to keep my cell phone with me all the time. & 134 & 1 & 5 & 2.31 & 1.37 \\
\hline I get irritated when a call or text on my cell phone interrupts me. & 134 & 1 & 5 & 3.36 & 1.20 \\
\hline
\end{tabular}

Table-13. Obliquely rotated component loadings for 7 survey items

\begin{tabular}{lcc}
\hline Component & 1 & 2 \\
\hline My cell phone gives me more freedom because I can stay in touch. & .798 & .002 \\
I like that my cell phone makes it easy to change plans quickly & .750 & .030 \\
I feel safer because I can always use my cell phone to get help. & .719 & .012 \\
I like to use my cell phone to keep in touch no matter where I am. & .697 & .151 \\
When I am bored, I use my cell phone to entertain myself. & .471 & .116 \\
It is a lot of trouble to keep my cell phone with me all the time. & .066 & .824 \\
I get irritated when a call or text on my cell phone interrupts me. & .090 & 1.380 \\
\hline Eigenvalues & 2.44 & 1.38 \\
Percentage of total variance & 34.80 & 19.7 \\
Cronbach Alpha & 0.72 & 0.68 \\
\hline
\end{tabular}

*Loadings $=>.10$

The results of an orthogonal rotation of the solution are shown in Table-13. When loadings less than 0.10 were excluded, the analysis yielded a two-factor solution with a simple structure. Factor 1, to some extent, captures the concept of nomophobia. This factor was analyzed further to see if any of the demographic variables had an impact on this construct.

One way Anova with Nomophobia (Factor 1) as the dependent variable and gender as the factor was significant at the .05 level. Females had a higher level of nomophobia when compared to their male counterparts. The results of the Anova are shown in Table-14 and Table-15.

\begin{tabular}{|c|c|c|c|c|c|c|c|c|}
\hline \multicolumn{9}{|c|}{ Table-14: Descriptive } \\
\hline \multicolumn{9}{|c|}{ Nomophobia (Factor1) } \\
\hline & \multirow[b]{2}{*}{$\mathrm{N}$} & \multirow[b]{2}{*}{ Mean } & \multirow[b]{2}{*}{$\begin{array}{c}\text { Std. } \\
\text { Deviation }\end{array}$} & \multirow[b]{2}{*}{$\begin{array}{l}\text { Std. } \\
\text { Error }\end{array}$} & \multicolumn{2}{|c|}{$\begin{array}{l}\text { 95\% Confidence } \\
\text { Interval for Mean }\end{array}$} & \multirow[b]{2}{*}{ Minimum } & \multirow[b]{2}{*}{ Maximum } \\
\hline & & & & & $\begin{array}{l}\text { Lower } \\
\text { Bound }\end{array}$ & $\begin{array}{l}\text { Upper } \\
\text { Bound }\end{array}$ & & \\
\hline Male & 66 & 4.4303 & .55052 & .06776 & 4.2950 & 4.5656 & 3.20 & 5.00 \\
\hline Female & 59 & 4.6305 & .46060 & .05997 & 4.5105 & 4.7505 & 3.20 & 5.00 \\
\hline Total & 125 & 4.5248 & .51785 & .04632 & 4.4331 & 4.6165 & 3.20 & 5.00 \\
\hline
\end{tabular}




\section{Issues in Information Systems}

Volume 13, Issue 2, pp. 33-40, 2012

\begin{tabular}{|l|r|r|r|r|r|}
\hline \multicolumn{7}{|c|}{ Table-15: ANOVA } \\
\hline & $\begin{array}{c}\text { Sum of } \\
\text { Squares }\end{array}$ & \multicolumn{1}{|c|}{ df } & $\begin{array}{c}\text { Mean } \\
\text { Square }\end{array}$ & F & Sig. \\
\hline Between Groups & 1.249 & 1 & 1.249 & 4.799 & .030 \\
\hline Within Groups & 32.004 & 123 & .260 & & \\
\hline Total & 33.253 & 124 & & & \\
\hline
\end{tabular}

According to study by Compete [5], women appear to be more likely to perform a range of activities on their smartphones than men. This study found that text messaging was performed by $98 \%$ of females and $92 \%$ of males; women were more active accessing social networking sites (79\% vs. $68 \%$ ), playing games ( $76 \%$ vs. $66 \%$ ), sharing photos/videos (73\% vs. $65 \%$ ) and conducting financial transactions (60\% vs. $48 \%)$. The findings of our research on nomophobia are consistent with the study done by Compete.

\section{CONCLUSIONS}

Universities will have to continue to shape their curriculums to meet the demands of increasingly connected students. Use of smartphone in the classroom is a cause of major concerns for many instructors, especially those who see smartphones as a distraction. Many students continue to access BlackBoard on their smartphones and receive updates from universities on their smartphones. There have, however, been very few success stories of integrating use of smartphones in university courses.

The millennial (generation of people born from 1977 to 2002) are of the opinion that they can multi-task; therefore, using smartphones in the classroom should not offend professors [5, 6]. However, as instructors, we know that it is impossible to pay attention to a lecture and use a smartphone at the same time. Furthermore, as instructors, we have the responsibility of teaching our students what is appropriate in the work-place, and most workplaces do not appreciate an employee using his or her cell phone while working.

Social Media sites have captured the imagination of our students, who spend a considerable amount of time them. Educators need to gain more insight on what their students are doing on these sites. Recruiters have been looking into the activities of potential hires on the social media sites, with some HR pros either asking applicants to hand over Facebook login credentials (including user names, passwords, security questions, etc.) or asking applicants to $\log$ into their Facebook accounts on a company computer. Some recruiters have even asked applicants to add them as a friend on the social network.

The focus of this research was to understand the penetration of smartphones among students and how the students use these devices. This information is important for educators as we plan for designing courses for the students of the future.

\section{REFERENCES}

1. Ball State University (2012) College Students: Mobile Ads Are Annoying http://www.mediapost.com/publications/article/168372/college-students-mobile-ads-areannoying.html?print\#ixzz1nD5E9N00. Accessed on May 1, 2012.

2. Brandt, Jessica and Heller, Michael (2007). Learning Unplugged: Using Cell Phones in Language and Culture Courses, Paper presented at American Council on the Teaching of Foreign Languages, San Antonio, TX, Nov 12,2007

3. Bullas, Jeff (2012) 11 New Twitter Facts, Figures and Growth Statistics plus http://www.jeffbullas.com/2011/09/21/11-new-twitter-facts-figures-and-growth-statistics-plus-infographic/ 


\section{Issues in Information Systems}

Volume 13, Issue 2, pp. 33-40, 2012

Accessed on May 1, 2012.

4. Clark, Dennis (2010). Text messaging: a lecture hall epidemic?

http://www.ecampusnews.com/technologies/text-messaging-a-lecture-hall-epidemic/, Accessed on April 10, 2012.

5. Compete (2012) The Male vs, Female Debate Goes Mobile- http://blog.compete.com/2011/11/29/the-male-vsfemale-debate-goes-mobile/ Accessed on May 1, 2012.

6. Ehow (2010). Social Disadvantages of Mobile Phones, http://www.ehow.com/list 6325088 social-disadvantages-mobile-phones.html Accessed on April 10, 2010.

7. Gartner (2011). Gartner Says Worldwide PC Shipments in Fourth Quarter of 2011 Declined 1.4 Percent http://www.gartner.com/it/page.jsp?id=1893523. Accessed on May 1, 2012.

8. Gartner (2011). Gartner Says Worldwide Smartphone Sales Soared in Fourth Quarter of 2011 With 47 Percent Growth http://www.gartner.com/it/page.jsp?id=1924314. Accessed on May 1, 2012.

9. Harris Interactive. (2008) A Generation unplugged - Research Report. Harris Interactive. http://files.ctia.org/pdf/HI_TeenMobileStudy_ ResearchReport.pdf Accessed January 10, 2011

10. Lenhart, Amanda, Ling, Rich and Campbell, Scott (2010) Teens and Mobile Phones, Pew Research Foundation, Washington, D.C.

11. Ling, Rich. (2008). New Tech, New Ties: How mobile communication is reshaping social cohesion. Cambridge: MIT Press.

12. Neilsen (2012) State of the Media: The Mobile Media Report Q3 2011 http://www.nielsen.com/us/en/insights/reports-downloads/2011/state-of-the-media--mobile-media-report-q32011.html. Accessed on May 1, 2012.

13. Neilsen (2012) State of the Media: The Social Media Report Q3 2011 http://www.nielsen.com/us/en/insights/reports-downloads/2011/social-media-report-q3.html. Accessed on May $1,2012$.

14. NorthEastern University (2011). Classroom technology requires academic reboot. http://www.northeastern.edu/news/2012/04/teaching_tech/, Accessed April 10, 2012.

15. Ran Wei, Ven-Hwei Lo (2006) Staying connected while on the move: Cell phone use and social connectedness New Media Society Feb 01, 2006; 8: 53-72.

16. Silk, Matt (2010). Marketing to the Ubiquitous Cellphone, E-Commerce Times, Feb. 23, 2010.

17. University of Chicago (2008). University of Chicago Law School eliminates Internet access in some classrooms http://news.uchicago.edu/news.php?asset_id=1329. Accessed April 10, 2012. 